\title{
CHITINASE PRODUCTION BY STREPTOMYCES SP. ANU 6277
}

\author{
Kolla J.P. Narayana, Muvva Vijayalakshmi* \\ Department of Microbiology, Acharya Nagarjuna University, Guntur-522 510, A.P., India
}

Submitted: April 06, 2008; Returned to authors for corrections: February 10, 2009; Approved: July 24, 2009.

\begin{abstract}
Chitinase production by a terrestrial Streptomyces sp. ANU 6277 was studied under sub-merged fermentation. Chitinase production started after $24 \mathrm{~h}$ of incubation and reached maximum levels after $60 \mathrm{~h}$ of cultivation. A high level of chitinase activity was observed in the culture medium with pH 6 at $35^{\circ} \mathrm{C}$. Culture medium amended with $1 \%$ chitin was found to be suitable for maximum production of chitinase. An optimum concentration of colloidal chitin for chitinase production was determined. Studies on the influence of additional carbon and nitrogen sources on chitinase production revealed that starch and yeast extract served as good carbon and nitrogen sources to enhance chitinase yield. Chitinase was purified from crude enzyme extract by single step gel filtration by Sephadex G-100. Purified chitinase of the strain exhibited a distinct protein band near $45 \mathrm{kDa}$ by means of SDS-PAGE.
\end{abstract}

Key words: Chitinase, Streptomyces sp. ANU 6277, Optimization, Characterization

\section{INTRODUCTION}

Actinomycetes, particularly Streptomyces spp. have been a widely exploited group of microorganisms in the production of secondary metabolites and enzymes of commercial importance in medical and agricultural applications (11). Several chitinolytic enzymes have been identified in several Streptomyces spp. including S. antibioticus, $S$. griseus, $S$. plicatus, $S$. lividans, $S$. aureofaciens and $S$. halstedii $(21,9)$. Chitinase has received attention due to its use as a biocontrol agent $(14,25)$ and also for developing transgenic plants (3). They have been used in a biological research for the generation of fungal protoplasts to degrade the fungal cell wall and also for being employed in human health care such as making ophthalmic preparations with chitinases (4). An actinomycete strain isolated from laterite soils of Acharya Nagarjuna University campus was identified by $16 \mathrm{~S}$ rRNA analysis and designated as Streptomyces sp. ANU 6277. The taxonomic study of the strain which was reported previously (15) showed that it was closely related to the Streptomyces albidoflavus cluster. In the present study, an attempt was made to optimize the culture conditions for the production of chitinase by the strain and its characterization.

\section{MATERIALS AND METHODS}

A pure culture of the strain, Streptomyces sp. ANU 6277 was maintained on a yeast extract- malt extractdextrose agar (ISP-2) medium. Colloidal chitin was prepared according to the method described by Sandhya et al. (20).

*Corresponding Author. Mailing address: Department of Microbiology, Acharya Nagarjuna University, Guntur-522 510, A.P., India.; E-mail: profmvl@gmail.com 
A culture suspension of the strain was inoculated in a chitinyeast extract-salts (CYS) medium (g.L $\left.\mathrm{L}^{-1}\right)$ : chitin, 5.0; yeast extract, $\quad 0.5 ; \quad \mathrm{K}_{2} \mathrm{HPO}_{4}, \quad 2.0 ; \quad \mathrm{MgSO}_{4} 7 \mathrm{H}_{2} \mathrm{O}, \quad 1.0 ; \quad$ and $\mathrm{FeSO}_{4} 7 \mathrm{H}_{2} \mathrm{O}, 0.1$ and final $\mathrm{pH}$ of the medium adjusted to 7 . For every $12 \mathrm{~h}$ intervals up to $84 \mathrm{~h}$, a culture filtrate was collected and used as an enzyme source. The harvested cells attained through the filtration were used for biomass estimation which was determined by the cell-dry-weight.

\section{Chitinase assay}

Extracellular chitinase activity was determined by incubating $1 \mathrm{ml}$ of crude enzyme with $1 \mathrm{ml}$ of $1 \%$ colloidal chitin in a $0.05 \mathrm{M}$ phosphate buffer, $\mathrm{pH} 7.0$ at $35^{\circ} \mathrm{C}$ for $1 \mathrm{~h}$. After centrifugation of reaction mixture, the amount of $\mathrm{N}$ acetyl-D-glucosamine released in the supernatant was determined by the method of Reissig et al., (19) using Nacetyl-D-glucosamine (NAG) as a standard. NAG present in $0.5 \mathrm{~mL}$ of aliquot of supernatant was determined by adding $0.1 \mathrm{ml}$ of $\mathrm{K}_{2} \mathrm{~B}_{4} \mathrm{O}_{7}$ and then boiled for $3 \mathrm{~min}$ in a water bath. The tubes were cooled and $3 \mathrm{ml}$ of pdimethylaminobenzaldehyde was added. Absorbance was read within $10 \mathrm{~min}$ at $585 \mathrm{~nm}$ against the blank prepared with distilled water without the enzyme presence. One unit (U) of chitinase is defined as the amount of enzyme which releases $1 \mu \mathrm{M} \mathrm{N}$-acetyl-D-glucosamine per hour under the conditions of the study.

\section{Optimization of chitinase production}

An optimum level of chitin concentration on chitinase production was determined by amending different concentrations of chitin in a CYS medium. The impact of $\mathrm{pH}$ and temperature on chitinase production was investigated by cultivating strain in the CYS medium at various $\mathrm{pH}(4-9)$ and temperature $\left(15-45^{\circ} \mathrm{C}\right)$ ranges for $60 \mathrm{~h}$. The carbon sources as starch, glucose, maltose, cellulose and arabinose and nitrogen sources such as ammonium chloride, ammonium sulphate, sodium nitrate, potassium nitrate, L-asparagine, L-glutamine, soybean meal, peptone and yeast extract were supplemented with the CYS medium to study their influence on chitinase production. There were three sets of flasks were maintained. One set of flasks contained the CYS (1\% chitin) medium supplemented with respective carbon and nitrogen sources whereas another set, besides the amended CYS medium and respective carbon and nitrogen sources was not supplemented with chitin. The third set, as control flasks, had its CYS medium kept constant (24).

\section{Utilization of fungal biomass as a source of chitin for chitinase production}

Fusarium oxysporum and Penicillium citrinum were grown in Czapek-Dox broth. After 15 days of incubation, the fungal mat was harvested and autoclaved at $121^{\circ} \mathrm{C}, 15 \mathrm{lbs}$ for $20 \mathrm{~min}$. The autoclaved fungal mat was washed twice with sterile distilled water and dried in an oven at $80^{\circ} \mathrm{C}$ till constant weight (6). The dried fungal mat was powdered and used as chitin source $\left(2\right.$ g. $\left.\mathrm{L}^{-1}\right)$ for the production of chitinases. Utilization of fungal mat by the strain for chitinase production was determined by using three sets of flasks -1) CYS medium in which colloidal chitin was replaced by fungal mat (2 g/l), 2) CYS medium supplemented with fungal mat (2 g/l) and 3) Control only with CYS medium without any fungal mat.

\section{Purification of chitinase}

A single-step purification of chitinases was performed according to the method suggested by Nawani and Kapadnis (16). The culture filtrate $(500 \mathrm{~mL})$ of 60 -h old culture broth was subjected to precipitation with ammonium sulphate to $80 \%$ saturation and kept at $4^{\circ} \mathrm{C}$ for $24 \mathrm{~h}$. The precipitate thus obtained was collected by centrifugation at $10,000 \mathrm{~g}$ for 20 min. The pellet was dissolved in a $0.01 \mathrm{M}$ citrate phosphate buffer, pH 6 and extensively dialyzed against the same buffer. The protein concentrate was loaded on Sephadex G100 (Sigma, USA) column $(2 \times 40 \mathrm{~cm})$ pre-equilibrated with a $0.01 \mathrm{M}$ citrate phosphate buffer, $\mathrm{pH} 6$ and eluted with the same buffer. Fractions thus collected were tested for chitinolytic activity. Chitinolytic active fractions were recovered and concentrated. 
Enzyme concentrate thus obtained through a gel filtration was checked for purity by SDS-PAGE (12) and its molecular weight was determined by comparing with known standard proteins. SDS-PAGE was carried out in a $2 \mathrm{~mm}$ slab gel of $10 \%$ acrylamide in a Tris- $\mathrm{HCl}$ buffer $(\mathrm{pH} 8.0)$ containing $0.1 \%$ SDS. Enzyme samples of $20 \mu \mathrm{L}$ were loaded into the wells. After electrophoresis, the gel was stained with $0.025 \%$ Coomassie brilliant blue R-250. The gel was destained with a solution (10\% v/v glacial acetic acid and $30 \%$ $\mathrm{v} / \mathrm{v}$ methanol in distilled water) till a clear background of the gel was obtained. The bands present on the gels were observed and compared with standard proteins. SDS-PAGE broad-molecular weight range proteins were used as standard proteins (Bio-Rad, USA).

Assay of chitinolytic activity of partially purified chitinase

Chitinolytic activity of the partially purified enzyme was examined by agar well diffusion method (21). Enzyme (50 $\mu \mathrm{L})$ was added to the wells of CYS agar medium plates. Control was maintained with $50 \mu \mathrm{L}$ of heat inactivated enzyme. Chitinolytic zones around the wells were observed after $12-24 \mathrm{~h}$ of incubation.

\section{Inhibition of fungal growth by partially purified chitinase} from the strain

Fusarium udum MTCC 2204 the causative agent of wilt of Cajanus cajan L. was cultured on a Czapek-Dox agar (CDA) medium (15). Spore suspension was spread onto the plates of CDA. Antifungal activity of purified chitinase against $F$. udum was studied by agar well diffusion method (21). Chitinase $(50 \mu \mathrm{L})$ of the strain was placed in wells of the CDA plate. Control was maintained with heat inactivated $50 \mu \mathrm{L}$ of purified enzyme. Inhibition of fungal growth was observed after 3-5 days.

\section{RESULTS AND DISCUSSION}

\section{Effect of incubation period on chitinase production}

The effect of the course of time on chitinase production by the strain is presented in Figure 1. Chitinase production was initially found after $24 \mathrm{~h}$ of incubation and reached maximum levels after $60 \mathrm{~h}$ of cultivation. Chitinase synthesis was found to decline as the incubation period further extended. Nawani et al., (18) reported the maximum production of extracellular chitinase by Microbispora sp. V2 after $48 \mathrm{~h}$ of incubation which declined subsequently. Nawani and Kapadnis (17) reported that the production of chitinase by Streptomyces sp. NK1057 was high after 5 days of incubation while Joo (9) found that maximum yield of chitinase by Streptomyces halstedii after $72 \mathrm{~h}$ of incubation.

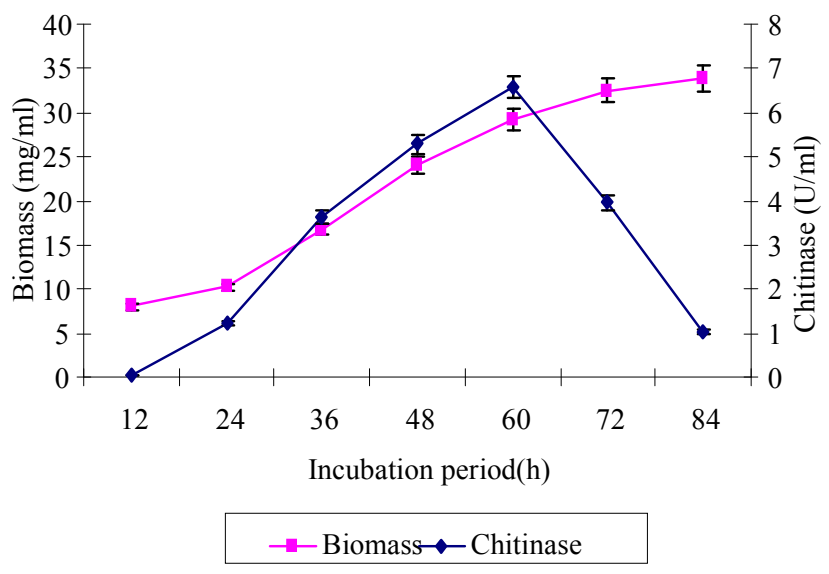

Figure 1. Effect of course of time on chitinase and biomass production (values are means of three replicates \pm SD)

\section{Effect of chitin concentration on chitinase production}

Optimal concentration of chitin for maximum chitinase production was studied (Fig. 2). Culture medium amended with $1 \%$ chitin exhibited maximum enzyme activity. It was in confirmity with the finding of Taechowisan et al. (21), who reported that the production of the chitinase from $S$. aureofaciens CMU Ac 130 was optimal with 1\% colloidal chitin concentration. According to Gupta et al. (8), S. viridificans produced maximum levels of chitinase in $1.5 \%$ of 
chitin amended medium after six days of incubation at $30^{\circ} \mathrm{C}$.

The strain ANU 6277 produced maximum chitinase in CYS medium amended with $1 \%$ chitin after $60 \mathrm{~h}$ of incubation.

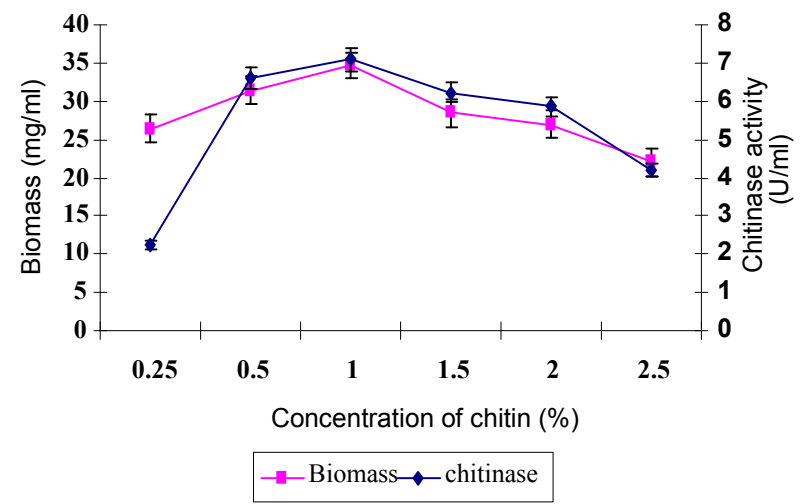

Figure 2. Role of chitin concentration on chitinase and biomass production (values are means of three replicates \pm $\mathrm{SD})$

\section{Impact of pH and temperature on chitinase production}

The influence of $\mathrm{pH}$ and temperature on chitinase production by the strain is depicted in Figure 3. Chitinase production varied as medium $\mathrm{pH}$ changed between 4 and 9. A high level of chitinase activity was observed in the culture medium with $\mathrm{pH} 6$ and optimum temperature for chitinase production was at $35^{\circ} \mathrm{C}$. In Microbispora sp. V2, the optimum $\mathrm{pH}$ and temperature for chitinase production were reported to be 7 and $40^{\circ} \mathrm{C}$ (18). Taechowisan et al., (21) reported that the production of chitinase by $S$. aureofaciens was optimal at $\mathrm{pH} 6.5-7$ and temperature $30-40^{\circ} \mathrm{C}$. Maximum chitinase production by the strain ANU 6277 was observed in $1 \%$ chitin amended CYS medium incubated at $\mathrm{pH} 6$ and temperature $35^{\circ} \mathrm{C}$ for $60 \mathrm{~h}$.

Influence of different carbon and nitrogen sources on chitinase production

The influence of additional carbon and nitrogen sources

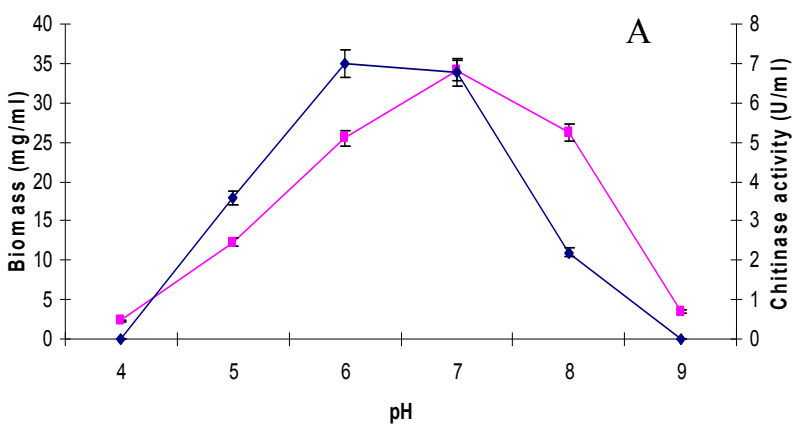

Biomass $(\mathrm{mg} / \mathrm{ml}) \rightarrow$ chitinase $(\mathrm{IU} / \mathrm{ml})$

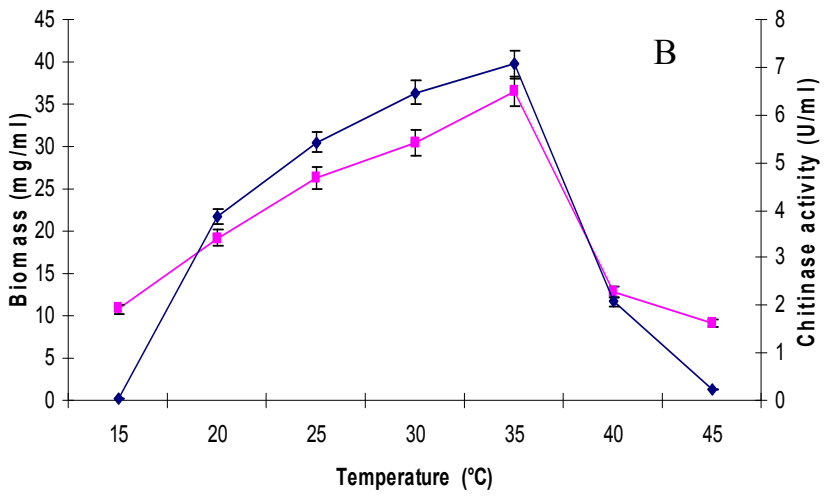

Figure 3. Impact of A) $\mathrm{pH}$ and $\mathrm{B}$ ) temperature on chitinase and biomass production (values are means of three replicates $\pm \mathrm{SD})$

on chitinase production was studied by supplementing different carbon and nitrogen compounds to CYS broth. Data on the effect of several carbon sources on chitinase production by the strain are presented in Table 1. Enhanced chitinase production was found in CYS medium amended with $0.2 \%$ starch, while enzyme production was suppressed in the CYS medium with glucose and arabinose. Cellulose and maltose did not influence chitinase production as compared to control. In $S$. viridificans, chitin medium amended with arabinose with chitin, enhanced the production of chitinase (8). Joo (9) reported that glucose (0.4\%) along with chitin induced high levels of chitinase by $S$. halstedii. Taechowisan et al. (21) found that amendment of pectin, 
starch and carboxymethyl cellulose to the colloidal chitin medium increased chitinase production by $S$. aureofaciens.

Table 1. Influence of additional carbon sources on chitinase production by the strain ANU 6277 cultured in CYS medium

\begin{tabular}{lcc}
\hline Carbon sources & \multicolumn{2}{c}{ Chitinase activity } \\
& $\left(\mathbf{U} . \mathbf{m L}^{-1}\right)$ & \pm SD \\
\hline${ }^{*}$ Control & 6.98 & \pm 0.17 \\
Starch $(0.2 \%)$ & 7.22 & \pm 0.08 \\
Starch $(0.4 \%)$ & 6.14 & \pm 0.30 \\
Glucose (0.2\%) & 4.16 & \pm 0.21 \\
Glucose $(0.4 \%)$ & 1.45 & \pm 0.07 \\
Cellulose (0.2\%) & 6.5 & \pm 0.14 \\
Cellulose (0.4\%) & 6.12 & \pm 0.05 \\
Maltose (0.2\%) & 6.19 & \pm 0.51 \\
Maltose (0.4\%) & 6.05 & \pm 0.26 \\
Arabinose (0.2\%) & 3.06 & \pm 0.19 \\
\hline * CYS medium with $1 \%$ chitin; Mean \pm SD from three \\
experiments
\end{tabular}

Among the different inorganic nitrogen sources supplemented to CYS medium, none could enhance chitinase production as compared to CYS medium (Table 2). However, there was a significant increase in chitinase production in CYS medium amended with organic nitrogen sources as yeast extract $(0.4 \%)$ and soybean meal $(0.6 \%)$. Vaidya et al., (24) reported that organic nitrogen sources as yeast extract and peptone significantly increased the chitinase production by Alcaligenes xylosoxydans. In the present study, CYS medium amended with starch (chitin, 1\%; starch, 0.2\%; yeast extract, $0.4 \% ; \mathrm{K}_{2} \mathrm{HPO}_{4}, 0.2 \% ; \mathrm{MgSO}_{4} 7 \mathrm{H}_{2} \mathrm{O}, 0.1 \%$ and $\mathrm{FeSO}_{4} 7 \mathrm{H}_{2} \mathrm{O}, 0.01 \%$ ) with $\mathrm{pH} 6$ was found to be suitable for maximum production of chitinase by the strain cultured at $35^{\circ} \mathrm{C}$ for $60 \mathrm{~h}$.

\section{Role of fungal biomass on chitinase production}

As the fungal cell wall contains chitin as the major component, chitinase are well known to lyse the cell wall of both live and dead fungi (23). Utilization of dead mass of $F$. oxysporum and $P$. citrinum by the strain for the chitinase production was studied (Fig. 4). Little enhancement of chitinase production was observed in CYS medium amended with dried fungal mats over CYS medium. The enzyme production was found to decline when the strain was cultured in CYS medium in which colloidal chitin was replaced by dried fungal mats as chitin source. Beyer and Diekmann (1) reported cell wall degradation of Penicillium chrysogenum by chitinase system of Streptomyces sp. ATCC 11238. An increase in chitinase production was observed from $S$. aureofaciens and $S$. halstedii when cultured in a medium containing colloidal chitin supplemented with fungal cell wall preparations $(9,21)$.

Table 2. Influence of additional nitrogen sources on chitinase production by the strain ANU 6277 cultured in CYS medium

\begin{tabular}{|c|c|c|}
\hline \multirow{2}{*}{$\begin{array}{l}\text { Nitrogen source }(\%) \\
\text { *Control }\end{array}$} & \multicolumn{2}{|c|}{$\begin{array}{c}\text { Chitinase activity } \\
\left(\text { U.mL }^{-1}\right) \pm \text { SD }\end{array}$} \\
\hline & 6.98 & \pm 0.17 \\
\hline $\mathrm{NH}_{4} \mathrm{Cl}(0.2 \%)$ & 3.68 & \pm 0.16 \\
\hline $\mathrm{NH}_{4}\left(\mathrm{SO}_{4}\right)_{2}(0.2 \%)$ & 5.68 & \pm 0.19 \\
\hline $\mathrm{NaNO}_{3}(0.2 \%)$ & 6.84 & \pm 0.09 \\
\hline $\mathrm{KNO}_{3}(0.2 \%)$ & 6.65 & \pm 0.23 \\
\hline L-glutamine $(0.2 \%)$ & 6.83 & \pm 0.57 \\
\hline L-asparagine $(0.2 \%)$ & 7.12 & \pm 0.39 \\
\hline Soybean meal $(0.2 \%)$ & 7.19 & \pm 0.07 \\
\hline Soybean meal $(0.4 \%)$ & 7.26 & \pm 0.30 \\
\hline Soybean meal $(0.6 \%)$ & 8.05 & \pm 0.24 \\
\hline Soybean meal $(0.8 \%)$ & 7.24 & \pm 0.76 \\
\hline Peptone $(0.2 \%)$ & 6.95 & \pm 0.69 \\
\hline Yeast extract $(0.2 \%)$ & 7.16 & \pm 0.50 \\
\hline Yeast extract $(0.4 \%)$ & 8.89 & \pm 0.34 \\
\hline Yeast extract $(0.6 \%)$ & 7.2 & \pm 0.65 \\
\hline
\end{tabular}




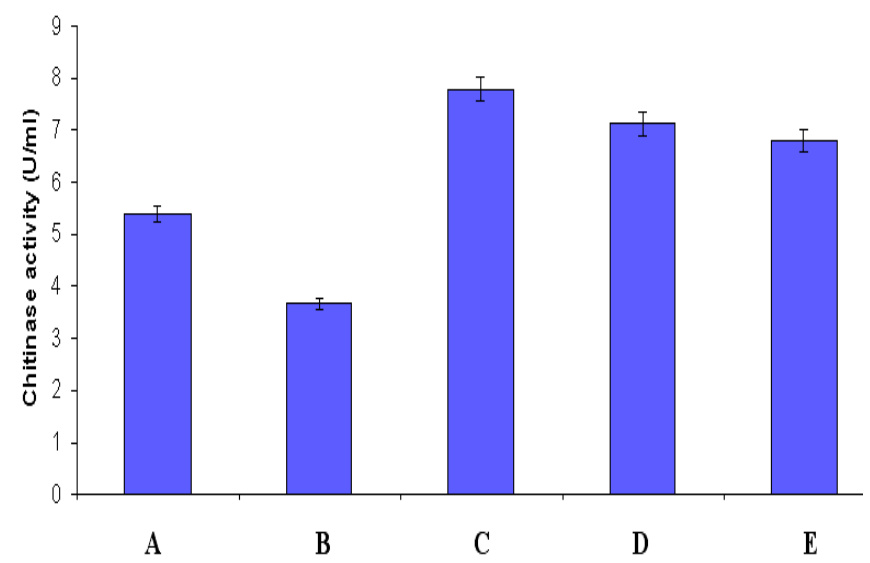

Figure 4. Utilization of dried fungal mat for chitinase production by Streptomyces sp. ANU 6277 (values are means of three replicates $\pm \mathrm{SD}$ )

A - CYS medium in which colloidal chitin was replaced by dried fungal mat of Fusarium oxysporum

B - CYS medium in which colloidal chitin was replaced by dried fungal mat of Penicillium citrinum

C - CYS medium supplemented with dried fungal mat of Fusarium oxysporum

D - CYS medium supplemented with dried fungal mat of Penicillium citrinum

E - Control only with CYS medium without any fungal mat

\section{Purification of chitinase}

The crude extract of enzyme was partially purified by a single-step procedure using Sephadex G-100 gel filtration. Proteins present in culture filtrate were extracted by ammonium sulphate $(80 \%)$. Dialyzed protein precipitate was subjected to gel filtration for purification. In the gel filtration, four protein peaks were observed but maximum chitinase activity was detected in the fractions of third peak (Fig.5). The purification steps are summarized in Table 3. Following Sephadex G-100 gel filtration, the purification of the chitinase was increased to 5 fold with over all yields of 46.2 $\%$. Chitinase of Microbispora sp.V2 was purified up to 6fold with 4.6\% recovery using Sephadex G-100 filtration (18). Purification of crude chitinase from Streptomyces sp.
M-20 was increased to 6-fold using DEAE-cellulose and Sephadex G-100 filtration (10).

Chitinolytic active fractions thus collected during gel filtration were concentrated and analyzed by SDS-PAGE for the determination of molecular weight of chitinase. Partially purified chitinase of the strain ANU 6277 revealed a distinct protein band near $45 \mathrm{kDa}$ (Fig. 6). Majority of bacterial chitinases were reported to be in the range of $\sim 20-60 \mathrm{kDa}$ (2). Chitinases from various Streptomyces were shown to possess molecular weights as $20 \mathrm{kDa}$ from Streptomyces $\mathrm{sp}$. M-20 (10), $28 \mathrm{kDa}, 35 \mathrm{kDa}$ and $45 \mathrm{kDa}$ from Streptomyces sp. NK 1057 (17), $43 \mathrm{kDa}$ and $45 \mathrm{kDa}$ from $S$. albovinaceus S-22(5), and $49 \mathrm{kDa}$ from $S$. griseus HUT 6037 (22) by SDSPAGE analysis.

The chitinase obtained by Sephadex G-100 gel filtration was tested for chitinolytic property on CYS agar medium. Partially purified enzyme was tested for chitinolytic property by cup-plate method. Controls were maintained with heat inactivated enzyme. Clear chitinolytic zones were observed around the wells loaded with $50 \mu \mathrm{L}$ of partially purified enzyme in CYS medium but heat inactivated enzyme failed to hydrolyze the colloidal chitin present in the CYS medium (Fig. 7A). Chitinases produced by Streptomyces spp. such as S. viridificans (8), S. lydicus WYEC 108 (13) and S. aureofaciens CMU Ac 130 (21) could hydrolyze colloidal chitin more rapidly than crude chitin or chitin from fungal cell walls.

Partially purified chitinase from strain was tested for antifungal activity against Fusarium udum. Controls were maintained with heat inactivated enzyme. Chitinase from the strain exhibited inhibitory activity against the growth of $F$. udum but heat inactivated enzyme taken as control did not show any antifungal activity (Fig. 7B). Kim et al., (10) determined the antifungal activity of purified chitinase from Streptomyces sp. M-20 against Botrytis cinerea by using agar diffusion test. Chitinases from Streptomyces were reported to exhibit several antifungal activities like inhibition of spore germination, germ tube elongation, bursting of spores and 
hypal tips $(21,7)$. In the present study, cultural exhibited antifungal activity against a phytopathogenic mold conditions were optimized for chitinase production by F. udum, it may be used as a biocontrol agent against wilt Streptomyces sp. ANU 6277 and the partially purified disease.

enzyme exhibited a protein band near $45 \mathrm{kDa}$. As the enzyme

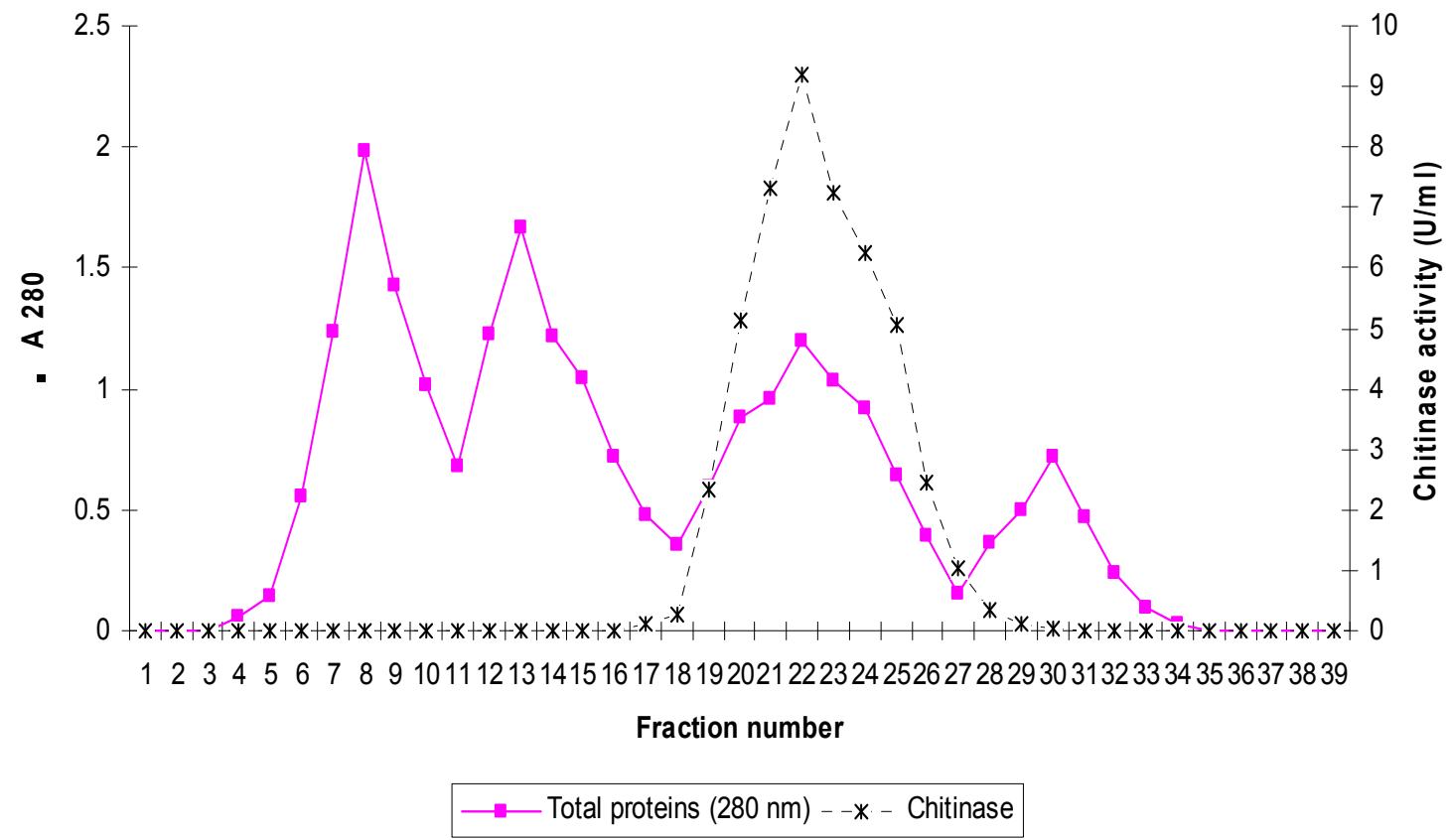

Figure 5. Chromatogram of the chitinase from Streptomyces sp. ANU 6277 on a Sephadex G-100 column. The column was eluted with $0.01 \mathrm{M}$ phosphate buffer, $\mathrm{pH} 7.0$

Table 3. Purification steps of extracellular chitinase from the strain ANU 6277

\begin{tabular}{lccccc}
\hline Purification step & $\begin{array}{c}\text { Total } \\
\text { proteins (mg) }\end{array}$ & $\begin{array}{c}\text { Total } \\
\text { activity(U) }\end{array}$ & $\begin{array}{c}\text { Specific activity } \\
\text { (U.mG } \mathbf{- 1})\end{array}$ & $\begin{array}{c}\text { Purification } \\
\text { (fold)(\%) }\end{array}$ & Yield (\%) \\
\hline Culture filtrate & 302 & 3570 & 11.8 & 0 & 100 \\
& 118 & 3120 & 26.4 & 2.2 & 87.4 \\
$\left(\mathrm{NH}_{4}\right)_{2} \mathrm{SO}_{4}$ & & & & 5 & 46.2 \\
$\begin{array}{l}\text { Precipitation } \\
\text { Sephadex G-100 }\end{array}$ & 27.5 & 1649 & 59.9 & 5 \\
\hline
\end{tabular}




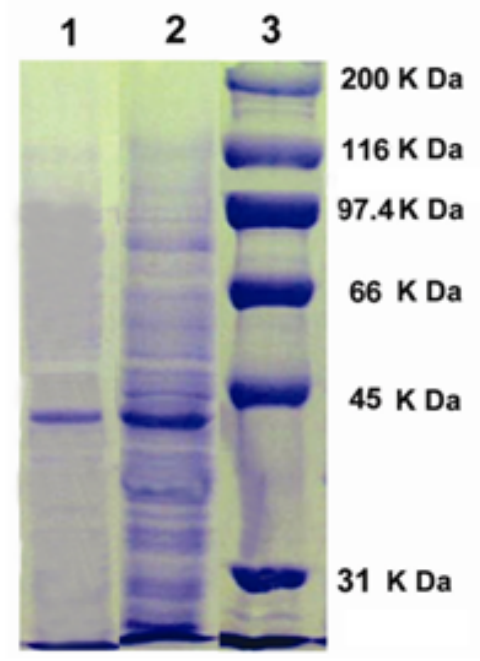

Figure 6. SDS-PAGE of chitinase from strain ANU 6277. Lane 1, Sephadex G-100 gel filtration fraction; Lane 2, Ammonium sulphate precipitate; Lane 3, Standard proteins.

A

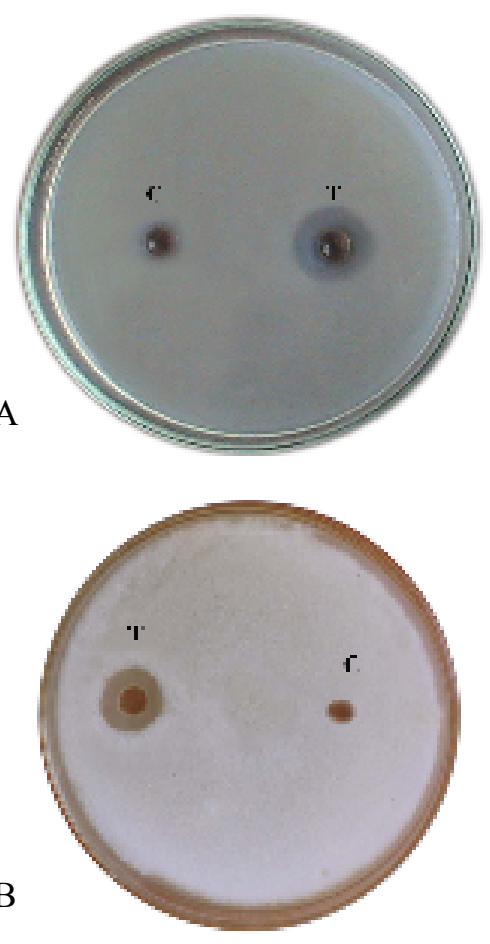

Figure 7. Chitinolytic activity (A) and Antifungal activity (B) of purified enzyme $(50 \mu \mathrm{L}) \mathrm{T}$ - Purified enzyme; $\mathrm{C}$ - heat inactivated enzyme (5-min boiled).

\section{ACKNOWLEDGEMENTS}

The author, KJPN, thankful to The Andhra PradeshNetherlands Biotechnology Programme (APNLBP), Hyderabad (INDIA) for providing financial support during work period.

\section{REFERENCES}

1. Beyer, M.; Diekmann, H. (1985). The chitinase system of Streptomyces sp. ATCC 11238 and its significance for fungal cell wall degradation. Appl. Microbiol. Biotechnol., 23, 140-146.

2. Bhattacharya, D.; Nagpure, A.; Gupta, R.K. (2007). Bacterial chitinases: properties and potential. Critical Rev. Biotechnol., 27, 2128 .

3. Bolar J.P.; Norelli, J.L.; Wong, K.W.; Hayes, C.K.; Harman, G.E.; Aldwinckle, H.S. (2000). Expression of endochitinase from Trichoderma harzianum in transgenic apple increase resistance to apple scab and reduced vigor. Phytopathol., 90, 72-76.

4. Dahiya, N.; Tewari, R.; Hoondal, G.S. (2006). Biotechnological aspects of chitinolytic enzymes: a review. Appl. Microbiol. Biotechnol., 71, 773-782.

5. El-Sayed, E.S.A.; Ezzat, S.M.; Ghaly, M.F.; Mansour, M.; El-Bohey, M.A. (2000). Purification and characterization of two chitinases from Streptomyces albovinaceus S-22. World J. Microbiol. Biotechnol., 16, 87-89.

6. Goel, V.; Chaudhary, T.; Vyas, P.; Chhatpar, H.S. (2004). Isolation and identification of marine chitinolytic bacteria and their potential in antifungal biocontrol. Indian J. Exp. Biol., 42, 715-720.

7. Gomes, R.C., Semedo, L.T., Soares, R.M.; Linhares, L.F.; Ulhoa, C.J.; Alviano, C.S.; Coelho, R.R. (2001). Purification of a thermostable endochitinase from Streptomyces RC 1071 isolated from a cerrado soil and its antagonism against phytopathogenic fungi. J. Appl. Microbiol., 90, 653-661.

8. Gupta, R.; Saxena, R.K.; Chaturvedi, P.; Viridi, J.S. (1995). Chitinase production by Streptomyces viridificans: its potential in fungal cell wall lysis. J. Appl. Bacteriol., 78, 378-383.

9. Joo, J.G. (2005). Purification and characterization of an extracellular chitinase from the antifungal biocontrol agent Streptomyces halstedii. Biotechnol. Lett., 27, 1483-1486.

10. Kim, K.J.; Yang, Y.J.; Kim, J.G. (2003). Purification and characterization of chitinase from Streptomyces sp. M-20. J. Biochem. Molecular Biol., 36, 185-189.

11. Kumar, D.; Gupta, R.K. (2006). Biocontrol of wood rotting fungi. Indian J. Biotechnol., 5, 20-25.

12. Laemmli, U.K. (1970). Cleavage of structural proteins during the assembly of the head of bacteriophage T4. Nature 277, 680-685. 
13. Mahadevan, B.; Crawford, D.L. (1997). Properties of the chitinase of the antifungal biocontrol agent Streptomyces lydicus WYEC 108. Enzyme Microbiol. Technol., 20, 209-217.

14. Mathivanan, N.; Kamilan, V.; Murugesan, K. (1998). Purification, characterization and antifungal activity of chitinase from Fusarium chlamydosporum, a mycoparasite to groundnut rust, Puccinia arachidis. Canadian J. Microbiol., 44, 646-651.

15. Narayana, K.J.P.; Prabhakar, P.; Vijayalakshmi, M.; Vekateswarlu, Y.; Krishna, P.S.J. (2007). Biological activity of phenylpropionic acid from a terrestrial Streptomycetes. Polish J. Microbiol., 56, 191- 197.

16. Nawani, N.N.; Kapadnis, B.P. (2001). One step purification of chitinase from Serratia marcescens NK1, a soil isolate. J Appl. Microbiol., 90, 803-808.

17. Nawani, N.N.; Kapadnis, B.P. (2004). Production dynamics and characterization of chitinolytic system of Streptomyces sp. NK 1057, a well equipped chitin degrader. World J. Microbiol. Biotechnol., 20, 487-494.

18. Nawani, N.N.; Kapadnis, B.P.; Das, A.D.; Rao, A.S.; Mahajan, S.K. (2002). Purification and characterization of a thermophilic and acidophilic chitinase from Microbispora sp. V2. J. Applied Microbiology., 93, 965-975.

19. Reissig, J.L.; Strominger, J.L.; Leloir, L.F. (1955). A modified colorimetric method for the estimation of N-acetyl amino sugars. $J$ Biol. Chem., 217, 959-966.

20. Sandhya, C.; Krishna, L.A.; Nampoothri, K.M.; Binod, P.; Szakacs, G.; Pandey, A. (2004). Extracellular chitinase production by Trichoderma harzianum in submerged fermentation. J. Basic Microbiol., 44, 49-58.

21. Taechowisan, T.; Peberdy, J.F.; Lumyong, S. (2003). Chitinase production by endophytic Streptomyces aureofaciens CMU Ac 130 and its antagonism against phytopathogenic fungi. Annal. Microbiol., 53, 447-461.

22. Tanabe, T.; Kawase, T.; Watanabe, T.; Uchida, Y.; Mitsutomi, M. (2000). Purification and characterization of a $49 \mathrm{kDa}$ chitinase from Streptomyces griseus HUT 6037. J. Biosci. Bioeng., 89, 27-32.

23. Ueno, H.; Miyashita, K.; Swada, Y.; Oba, Y. (1990). Purification and some properties of extracellular chitinase from Streptomyces sp. S-84. J. Gen. Appl. Microbiol., 36, 377-392.

24. Vaidya, R.J.; Shah, I.M.; Vyas, P.R.; Chhatpar, H.S. (2001). Production of chitinase and its optimization from a novel isolate Alcaligenes xylosoxydans: potential in antifungal biocontrol. World J. Microbiol. Biotechnol., 17, 691-696.

25. Zhu, Y.; Jieru P.; Junzhi.; Xiong G. (2008). Isolation and characterization of a chitinase gene from entomopathogenic fungus Verticillium lecanii. Braz. J. Microbiol., 39, 314-320. 